\title{
THE EFFECT OF SERVICE QUALITY ON REVISIT INTENTION IN TOURIST BEACH
}

\author{
Wilawan JANSRI * \\ Thaksin University, Faculty of Economics and Business \\ Administration, 9000o, Songkhla, Thailand, e-mail: wilawan@tsu.ac.th \\ Lubna A. HUSSEIN \\ Universiti Sains Malaysia, School of Distance Education, \\ 11800 USM, Penang, Malaysia, e-mail: lubnafatlawi@gmail.com \\ Joshua Teck Khun LOO \\ UOW KDU Penang University College, 32, Jalan Anson, George \\ Town, 10400 George Town, Pulau Pinang, e-mail: captjoshualoo@yahoo.com
}

\begin{abstract}
Citation: Jansri, W., Hussein, L.A. \& Loo, J.T.K. (2020). THE EFFECT OF SERVICE QUALITY ON REVISIT INTENTION IN TOURIST BEACH. GeoJournal of Tourism and Geosites, 29(2), 472-487. https://doi.org/10.30892/gtg.29208-483
\end{abstract}

\begin{abstract}
The purpose of beach management practices has widened in recent years, although there is still no complementary or bottom-up research that determines the preferences and demands of beach users. Therefore, this study seeks to evaluate the service quality perceptions of international tourists' intentions to revisit beach routes. The study uses a cross-sectional questionnaire survey to collect data from 185 respondents who are international tourists. Specifically, this paper aims to assess service quality perceptions of international tourists based on a survey conducted in Langkawi Island in Malaysia. The study employs PLS-SEM to analyse the data collected on service quality perceptions and the revisit intentions of tourists to beach routes. The study shows that three factors namely assurance, responsiveness and tangible have influences on the service quality perceptions of international tourists. The findings are fundamental for service providers to gain better insights into the perceptions of service quality of international tourists.
\end{abstract}

Key words: Service Quality, Revisit Intention, Beach Routes, Tourism, Malaysia

\section{INTRODUCTION}

International tourism has experienced rapid development in the past three decades, and this had attracted the attention of researchers, practitioners and governments from several countries, including Malaysia (Connell, 2006; Pemayun \& Suderana, 2019). The benefits of the development of the tourism industry are not felt only in the industry, but it also generates a significant economic flow that influences

\footnotetext{
* Corresponding author
}

http://gtg.webhost.uoradea.ro/ 
other sectors including stores, transport and building (Hui et al., 2007, Sadeh et al., 2012). Essentially, tourism businesses have the potentials to provide substantial revenues for a country through jobs creation for the unskilled, semi-skilled and skilled labour (Chen \& Tsai, 2007; Saner et al., 2019). Consequently, the government of Malaysia recognised the tourism industry as one of the National Key Economic Areas in the Government Change Programme which is necessary to spearhead the transformation of the country into a high-income nation by 2020 (Pemandu, 2010). This present study was conducted in Langkawi Island, a destination which is renowned for its exquisite beaches and different habitats that comprise mangrove wetlands, tropical rainforests, caves and coral reefs. The Malaysian government began the marketing of Langkawi as an important tourist destination since the 1980s, and this has resulted in the development of the facilities with a view to providing enhanced services.

Basically, Island destinations provide distinctive attractions because they signify excellent residing laboratories. Therefore, they provide crucial locations to investigate the effect of tourism development on Island tourists, residents, surroundings as well as the economic climate (Andriotis, 2004; Carlsen \& Butler, 2011; Moon \& Han, 2019). Conversely, Island development is usually confronted with several issues because of the complex interactions of various economic, social and environmental factors (Chapman, 2007; Kaltenborn et al., 2012; Royle, 2010). There is also the issue of how to transform an Island into a distinctive destination via tourism development so as to make it an important part of a modern tourism (Ryan, 2002; Wilkinson, 2012).

\section{REVIEW OF LITERATURE}

Nowadays, beaches signify the primary concentration of global travel, vacation and leisure, thereby making them to become the icons of modern tourism (Holden, 2000; Pereira \& Dantas, 2019; Retama et al., 2019). Nonetheless, the concentration of people and their activities in beaches are capable of causing the degradation of the surroundings ( Prata et al., 2020). These could have effects on the environment and the tourists' recreational experiences, which may be detrimental to the host interests (Fullana \& Ayuso, 2001; Tretiakova et al., 2019). Empirical literature (e.g. Cihar \& Stankova, 2006; Daily, 1997; Priskin, 2003; Song et al., 2019; Mujan et al., 2019; Rodella \& Corbau, 2020) posited that it is necessary to add public perceptions, needs and preferences relating to environmental quality to any evaluation so as to produce a better-informed and context-based process. As for tourist beaches, a wide-ranging and meaningful information relating to users' perceptions of beach quality are necessary to coastal managers to effectively plan the management of the environment and improve sustainable tourism.

The essence of this paper is to inform the management on the appraisal of the quality of the beaches situated in famous tourist areas. Hence, we examine the behaviours and perceptions of beach users regarding beach quality. More precisely, this study seeks to examine the demographic variables or determinants which influence the perceptions of beach users with a view to providing meaningful information to seaside executives.

\section{BACKGROUND ON BEACH QUALITY}

Although several scholars have investigated the perceptions of beach users (Tudor \& Williams, 2003; Villares et al., 2006), very few studies focused on the variety and factors that affect beach users. For instance, Williams et al. (1993) examined the sociodemographic factors which influence peoples' choice of beach, and reported that the three significant factors are gender, socioeconomic status and planned length of stay. According to Morgan et al. (1993), individuals of high socioeconomic status have the tendency to place a lower priority on visitor services but are often concerned about shortages of 
facilities including dearth of lavatories. Furthermore, Wolch and Zhang (2004) developed a conceptual model that relate the rates of beach use to the characteristics of individuals, geographical access, interactions with coastal environments, coastal knowledge and attitudes towards nature. However, these aspects were not absolutely independent because demographic factors could form environmental attitudes thereby performing an adverse role. The study failed to address the way diverse environmental attitudes or values could influence peoples' choice or preference of beach entertainment.

Although adequate empirical researches on this subject matter have not been conducted, Wolch and Zhang (2004) opined that individuals who have anthropocentric attitudes could make different choices compared to individuals with eccentric attitudes.

Based on the suggestions of the study, persons who have anthropocentric attitudes could have preferences for consumptive entertainment (e.g. restaurants, deck chairs, etc) and well-equipped beaches. Conversely, persons who have ecocentric attitudes could have preferences for other activities (e.g. walking, snorkelling, biodiversity observation, etc) and unspoiled beaches. Similarly, Tunstall and PenningRowsell (1998) conducted an empirical study on the meanings and values which individuals attach to experiences at the beach. Evidence from the study revealed that individuals related beaches to the concept of naturalness as well as to their previous personal experiences. There are some other essential studies that dealt with specific problems. For example, Pendleton et al. (2001) investigated the way perceptions of environmental quality and pollution-associated risks were connected to beach visitation. The study concluded that the information provided about a beach in the media had a significant influence on the perceptions of risk. Similarly, Bonaiuto et al. (1996) investigated how local and national identity processes influence the perception and assessment of beach pollution.

The study revealed that individuals who have greater attachment to their towns or nations have the tendency to consider their beaches (local and national) as less polluted. According to the study, these opinions represented the reactions to the physical evaluation enforced by external groups which could threaten the identity of a place. Lastly, the empirical researches conducted by Villares (1999) and Villares et al. (2006) focused on public perceptions or opinions of beach erosion processes.

\section{A FIVE STEPS PROCESS TO ASSESS BEACH QUALITY}

According to the methodological protocol, a research program on quality of beach consists of five steps. It is based on the notion that beach perception is a significant aspect of research which cannot be examined distinctly from the characteristics and frequentation of beach. The demarcation of beach sites is necessary to decide which aspect should be incorporated in the study with a view to assisting beach management comprehensibly. The degree of beach sites is contingent upon the physical and anthropogenic factors (e.g. extent of urbanisation and beach facilities). Figure 1 shows the five successive areas of the Langkawi Island beach sites from the land to sea. They include the access road to the beach, the parking area, the footpath, crossing the dune, the beach itself, and the bathing and water activation area (Figure 1).

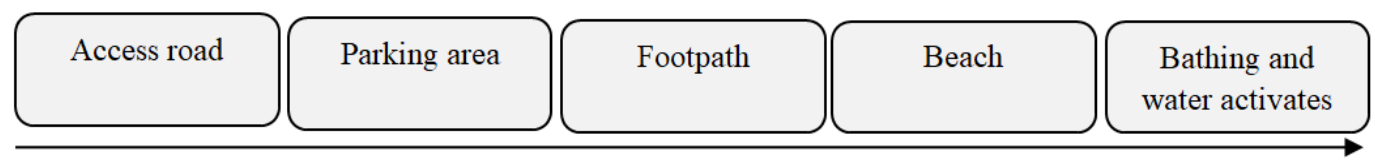

Land

Figure 1. Quality beach routes research programs 


\section{TOURIST REVISIT INTENTION (TRI)}

An investigation into the revisiting intentions of tourists remains an attractive and different type of tourism in contemporary tourism literature (Lam \& Hsu, 2006). There are differences in the choices and requirements for tourists which continues to experience modifications with several outlooks. Basically, one of the fundamental tasks of tourism entrepreneurs is how to obtain meaningful information regarding the comprehensive purchasing actions of tourists and utilize this information to forecast their future intentions to revisit. According to Wang (2004), it is cheaper to attract repeat visitors compared to new visitors. Moreover, it had been asserted that repeat visitors usually spend more money and stay longer compared to first-time visitors (Lehto et al., 2004; Wang, 2004). Therefore, an insight into revisit intention represents an essential issue for destination administrators since repeat visitors could provide greater income and decrease their travel expenses (Park \& Yoon, 2009; Li et al., 2010). Basically, behavioural intention is the origin of the notion of revisit intention.

Thus, a behavioural intention denotes an intention for preparing to perform a particular behaviour (Oliver, 2014). Individuals have greater likelihood of executing a specific behaviour whenever they possess greater or powerful intention to perform the behaviour (Sparks et al., 2002). As for the tourism and entertainment dimensions, this implies a repurchase of a tourism service, leisure service, or a revisit to a destination or visitor attraction (Akama \& Kieti, 2003). A large number of studies have revealed a significant connection among tourist satisfaction, revisit intention and positive recommendation (Som \& Badarneh, 2011). From the exploration perspective, Kandampully and Suhartanto (2000) reported that the two vital factors that influenced the behavioural intention of visitors include destination image and satisfaction.

Some empirical studies have also showed that motivation and satisfaction are fundamental factors that influenced behavioural intention (Van et al., 2013). The study also indicated that travel motivation such as family togetherness, relaxation, fun and safety have positive effects on revisit intention. In the competitive market of tourism destinations, revisit intention was considered as a crucial research subject. Despite the large amount of empirical studies on repeat visitors, it remains unclear the factors that enhance individuals repeat visitations as well as the type of characteristics that encourage repeat visitors (Assaker et al., 2011). Essentially, a behavioural intention signifies an intention of considering conducting a particular behaviour (Williams \& Hall, 2000).

From the perspective of consumption process, tourists' behaviour could be categorized into three distinct stages namely pre-visitation, during visitation, and post visitation (Rayan, 2002; William \& Buswell, 2003). Moreover, Chen and Tsai (2007) opined that tourists' behaviours encompass a choice of place to visit, following assessments, and future behavioural intentions. Thus, the subsequent assessments consist of the journey experiences or significant value and the general satisfaction of the visitors. Whereas the future behavioural intentions denote the view of the visitor regarding the likelihood to revisit the same destination as well as the motivation to recommend it to other visitors.

\section{SERVICE QUALITY (SQ)}

As a kind of view, service quality is evaluated by customers according to their knowledge of service delivery process which assesses their desires for the services they gained by this appraisal (Gronroos, 1984). Based on this distinction, service quality is contingent upon two features namely expected and perceived services. According to Gronroos (1984), previous experiences regarding a particular service could influence the requirement of the customer, whereas perceived services begin from the perception of the customer about the services. Practically, service quality represents a kind of perception 
which is related to the satisfaction of the customer. Nonetheless, it is not identical and generates via customer expectation in assessment of the operation of an organisation (Parasuraman, 1988). Table 1 presents the total quality management dimensions in nongovernmental sectors in line with quality professionals as follow:

Table 1. Total quality management dimensions (Source: Azizzadeh, 2013)

\begin{tabular}{ll}
\hline \multicolumn{1}{c}{ Latent variable } & \multicolumn{1}{c}{ Sources } \\
\hline Tangibles, reliability-responsiveness, credibility, empathy and commitment & Parasuraman (1998) \\
\hline $\begin{array}{l}\text { Quick delivery, accuracy, aesthetic, informing, appropriate behaviour- } \\
\text { legitimacy easiness }\end{array}$ & David Garvin (1993) \\
\hline $\begin{array}{l}\text { Humbleness, responsiveness-completeness, clarity, accuracy- } \\
\text { carefulness cleanliness }\end{array}$ & Keith smith (1993) \\
\hline $\begin{array}{l}\text { Tangibles, validity and reliability-sensitivity-personnel knowledge and } \\
\text { ability humbleness }\end{array}$ & Zeithaml (1996) \\
\hline Speed-courtesy-easiness and cleanliness-friendly interaction & Jayson (1998) \\
\hline $\begin{array}{l}\text { Availability-quick and smoother interaction-communication retention } \\
\text { communication quality-solidarity and honesty }\end{array}$ & Peter Sengh (1998) \\
\hline $\begin{array}{l}\text { Services accuracy and completeness guarantee, empathy and } \\
\text { cooperation-services permanent responsiveness }\end{array}$ & $\begin{array}{l}\text { Murray and Atkinson } \\
\text { (1998) }\end{array}$ \\
\hline
\end{tabular}

According to Parasuraman et al. (2002), the five dimensions of service quality (such as tangible, reliability, responsiveness, assurance and empathy) have high correlation with service performance. For instance, tangible comprises the physical facilities, equipment, and personal appearance, while reliability implies the ability of service employee to accomplish the service as promised. Besides, responsiveness signifies the desire of an employee to support and deliver prompt service, while assurance shows the ability, courtesy and knowledge of an employee to inspire trust. Finally, empathy indicates the quantity of caring and individualised attention which a firm offers to its customers. Although service quality comprises five dimensions such as tangibles, reliability, responsiveness, assurance and empathy, customer appraisal of service quality often does not utterly depend on the characteristics of the service. Hence, it is necessary to also consider other dimensions such as the customer's emotions or memory (Jiang \& Wang, 2006). Therefore, it could be inferred that service quality is determined by the customers based on the pleasure they obtain from a specific service (Malik, 2012).

Table 2. Definitions of dimensions of SEVQUAL model (Source: adopted by Lim et al.,1999)

\begin{tabular}{ll}
\hline Dimension & \multicolumn{1}{c}{ Definition } \\
\hline Tangibles & $\begin{array}{l}\text { Physical facilities, equipment, the external appearance of the store and } \\
\text { appearance of personnel. }\end{array}$ \\
\hline Reliability & Company's potential for performing the promised service dependably and accurately. \\
\hline Responsiveness & Company's willingness to help customers and provide prompt service. \\
\hline Assurance & $\begin{array}{l}\text { Employees' knowledge and courtesy levels and their ability to inspire trust and } \\
\text { confidence. This dimension alsoincludes competence, courtesy, credibility, and security. }\end{array}$ \\
\hline Empathy & $\begin{array}{l}\text { Caring and personalised attention that the firm provides to its customers. This } \\
\text { dimension also includes access, communication and understanding the customer. }\end{array}$ \\
\hline
\end{tabular}

Empirical literature has shown that pleasure, reliability and perceptions concerning the speed of delivery influence service quality perceptions (Shamdasani, Mukherjee, \& Malhotra, 2008). Basically, SERVQUAL model is the most renowned and utilized model among the models used to measure service quality in diverse industries. The SERVQUAL model proposed by Parasuraman et al. (1988) entails fivedimensions of measuring 
perceived service quality such as tangibles, reliability, responsiveness, assurance and empathy (Parasuramanet el al., 1988; Zeithamlet el al., 1990) (Table 2).

\section{TANGIBLE (IV1)}

According to Parasuraman et al. (1985), tangibility refers to the visual attraction of employees, physical facilities, equipment as well as written materials. As for their study on the private sector, Ananth et al. (2011) described tangibility as the possession of contemporary physical facility, equipment, properly dressed employees and creatively attractive elements. Therefore, this current study considers the definition of tangible in line with Ananth et al. (2011).

\section{$\boldsymbol{H}_{1:}$ Tangible has a positive influence on tourist revisit intention (TRI).}

\section{RELIABILITY (IV2)}

Reliability comprises accurate order fulfilment, records, quote, billing, computation of commissions as well as keeping services' promise. Basically, reliability encompasses dealing with service problems, accomplishing the right services at the first time, offering services at the appropriate or promised time as well as keeping flawless records. Parasuraman et al. (1988) posited that reliability represents the most essential element in conventional service. In the retail market, reliability denotes the period plans and exactness of service which employees utilize when handling visitor issues and accomplishing their promises to a tourist ( $\mathrm{He} \& \mathrm{Li}, 2011)$. It could have a significant effect on the perception of service quality by the customers. A previous research showed that reliability represents one of the fundamental characteristics upon which the service quality's expectations of the customers are formed (Dabholkar, 1996). Besides, reliability comprises accurate order fulfilment, records, quotes, billing, computation of commissions as well as keeping services' promise (Yang et al., 2004).

\section{$\boldsymbol{H}_{\mathbf{2}}$ Reliability has a positive influence on tourist revisit intention (TRI).}

\section{ASSURANCE (IV3)}

According to Parasuraman et al. (1985), assurance refers to the employees' knowledge, courtesy and capability to stimulate trust and confidence. In the service sector however, Sadek et al. (2010) described assurance as the existence of courteous and friendly staff, knowledgeable and experienced team of service provider, ease of access and interior comfort. This present study considers assurance as a vital element of inspiring the revisit intentions of international tourists.

\section{$\boldsymbol{H}_{3:}$ Assurance has a positive influence on tourist revisit intention (TRI).}

\section{EMPATHY (IV4)}

In the context of service quality, empathy is concerned with the way business cares for and offers individualised attention to their customers with a view to creating the feeling of highly specific and valued customers (Delgado \& Ballester, 2004). Moreover, Parasuraman et al. (1985) described empathy as the care and specific interest which a firm offers to its customers. It entails giving individual attention to customers and employees who understand the desires of their clients and convenience of business hours. In their study on private sector, Ananth et al. (2011) described empathy as the provision of distinct attention, suitable operational hours, offering individual attention as well as ideal attention in the heart based on the realization that the customers have individualized desires.

\section{$\boldsymbol{H}_{4}$ : Empathy has a positive influence on tourist revisit intention (TRI).}




\section{RESPONSIVENESS (IV5)}

Parasuraman et al. (1985) opined that responsiveness denotes the service provider's disposition or readiness to deliver service. It encompasses the appropriateness of services, understanding the international tourists' needs and desires, suitable hours of operations, specific individual attention, as well as giving prompt attention to handling problems and safety of the customers in their transactions (Kumar et al., 2009).

$\boldsymbol{H}_{5}$ : Responsiveness has a positive influence on tourist revisit intention (TRI).

\section{THE CONCEPTUAL RESEARCH FRAMEWORK AND HYPOTHESES DEVELOPMENT}

Figure 2 illustrates the proposed conceptual framework that was developed for this study. It employs this framework to determine the direct relationships between the independent variables (service quality dimensions such as tangible, reliability, responsiveness, assurance and empathy) and the dependent variables (tourist revisit intention) as shown in Figure 1. We developed the research hypotheses of this study based on the conceptual research framework. The conceptual model comprises five key hypotheses which are to be tested with Smart-PLS analysis.

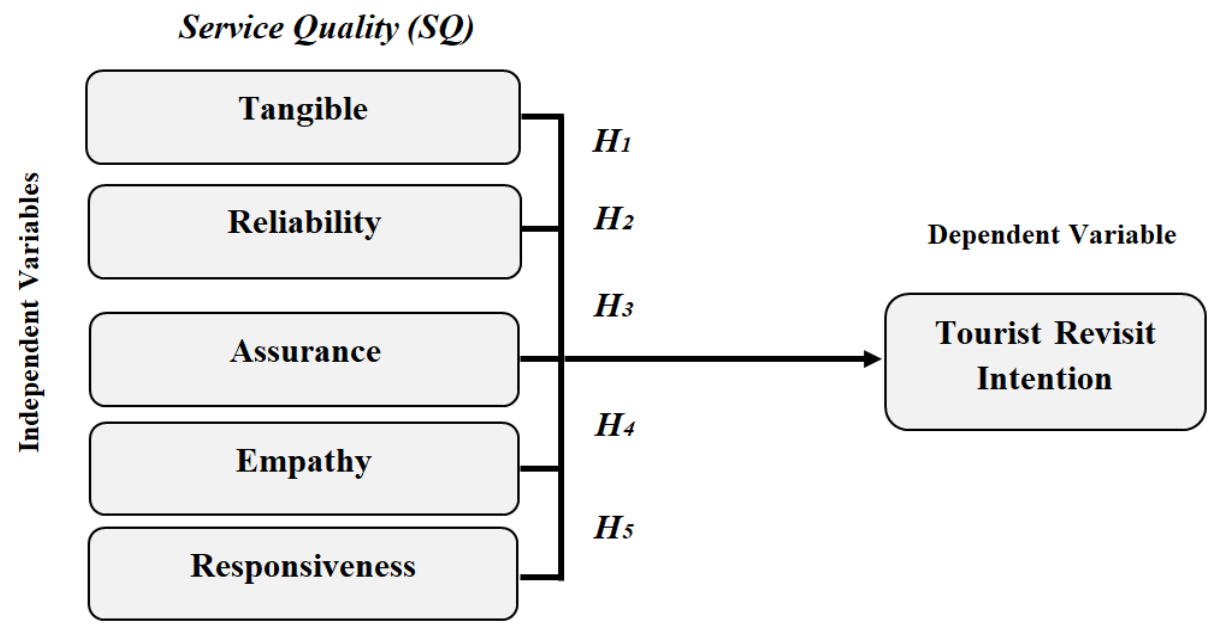

Figure 2. Conceptual Research framework with Hypothesized Relationships

\section{RESEARCH METHODOLOGY}

\section{Data collection procedure and sample}

This study employs a methodology that obtained information on tourist revisit intention by conducting a survey on a small sample drawn from the population of international tourists in Langkawi Island. The questionnaire used to obtain information from the respondents contained questions that were adapted from a past research.

It assesses service quality by focusing on the five dimensions of the "SERVQUAL" instrument with questions focused on each dimension. Therefore, the survey questionnaire was designed to focus on the considerations of the respondents (international tourists) on service quality. The questionnaires were designed for the specific respondents of the study who are the international tourists that visited Langkawi during the period of data collection. From the data collected from the international tourists, the responses of 185 respondents regarding the link between service quality perception and tourist revisit intentions were useable. 
These responses covered five dimensions of service quality such as tangible, reliability, responsiveness, assurance and empathy as well as the dependent variables (tourist revisit intention). The study employed random sampling and distributed about 220 questionnaires. However, only 195 questionnaires were returned, and out of which 185 questionnaires were used for data analysis. This study conducted Harman's single factor test to ascertain the absence of Common Method Bias in the questionnaire survey. It revealed that the first factor accounted for 21.224 of variance, and this value is lower than the threshold value of $50 \%$ of total variance explained.

From the 34 possible linear combinations, it was found that only 10 combinations were taken from the principal component analysis that fulfil the requirement on ten values which should be greater than one. Thus, the Eigenvalue should be greater than one so as to have a lower residual variance since the Eigenvalue ratio represents the ratio of explainable to unexplainable variation. Based on this process, it showed that $83.269 \%$ of the entire variation was explained by the ten factors, and this value is greater than the 50\% the threshold proposed by Podsakoff et al. (2003).

The statistics reported in Table 3 indicate that most of the respondents 125 (67.57\%) were first-time visitors to Langkawi Island, 56 (30.27\%) were second time, whereas very few $4(2.16 \%)$ were 3 to 5 -time visitors. Hence, the main targets of this study should be first-time visitors. The educational levels of the respondents revealed that $64(34.59 \%)$ of them had a bachelor's degree, 46 (24.86\%) of them possessed a diploma, 32 (17.30\%) of them had high school, and 31 (16.76\%) of them had a master's degree. The marital status of the respondents showed that $101(54.59 \%)$ of them were married, while $84(45.41 \%)$ of them were single. Regarding their preferences, 54 (29.19\%) of the respondents had preferences for water sports as the most enjoyable activities, whereas 32 (17.30\%) of them preferred a view and fresh air. As for the kind of accommodation, most of the respondents 120 (64.86\%) stayed in a hotel, and 33 (17.84\%) of them stayed in a guest house. Most of the international tourists 105 (56.76\%) of them stayed for a maximum length of 1-2 days, 68 (36.76\%) of them stayed for 3-7 days, very few respondents stayed for between 8-14 days. The age of the respondents showed that 40 (21.62\%) of them were more than 45 years old, $36(19.46 \%)$ of them were between 31 to 35 years old, and 34 (18.38\%) of them were between 21 to 25 years old. The gender of the respondents revealed that $95(51.35 \%)$ of them were male whereas 90 (48.65\%) of them were female. Regarding the sources of information, 72 (38.92\%) of the respondents obtained their information from the internet, while 59 (31.89\%) of them obtained their information from the words of mouth of a friend or relative. Finally, 72 (38.92\%) of the respondents indicated that they dislike litter. Table 3 presents the demographic profile and the travel patterns of the respondents.

Table 3. Profile of the respondents and travel pattern $(n=185)$

\begin{tabular}{lllcr}
\hline Variable & Description & Number of Respondents & \% \\
\hline \multirow{2}{*}{ Gender } & Male & 95 & 51.35 \\
\cline { 2 - 5 } & Female & 90 & 48.65 \\
\hline \multirow{4}{*}{ Age (Years) } & $21-25$ & 34 & 18.38 \\
\cline { 2 - 5 } & $26-30$ & 32 & 17.28 \\
\cline { 2 - 5 } & $31-35$ & 36 & 19.46 \\
\cline { 2 - 5 } & $36-40$ & 17 & 14.05 \\
\cline { 2 - 5 } & M1-45 & 40 & $\mathbf{2 1 . 6 2}$ \\
\cline { 2 - 5 } & More than 45 & 101 & 54.59 \\
\hline \multirow{2}{*}{ Marital status } & Married & 84 & 45.41 \\
\cline { 2 - 5 } & Single & & \\
\hline
\end{tabular}




\begin{tabular}{|c|c|c|c|}
\hline \multirow{6}{*}{ Education } & High School & 32 & 17.30 \\
\hline & Diploma & 46 & 24.86 \\
\hline & Bachelor's Degree & 64 & 34.59 \\
\hline & Master's degree & 31 & 16.76 \\
\hline & Ph.D./Doctorate & 6 & 3.24 \\
\hline & Other & 6 & 3.24 \\
\hline \multirow{3}{*}{ Number of visits } & First Time & 125 & 67.57 \\
\hline & Second Time & 56 & 30.27 \\
\hline & 3-5 Time & 4 & 2.16 \\
\hline \multirow{3}{*}{ Length of stay } & 1-2 Day & 105 & 56.76 \\
\hline & 3-7 Days & 68 & 36.76 \\
\hline & 8-14 Days & 12 & 6.49 \\
\hline \multirow{5}{*}{ Type of accommodation } & Guest house & 33 & 17.84 \\
\hline & Backpackers & 18 & 9.73 \\
\hline & Hotel & 120 & 64.86 \\
\hline & Lodge & 8 & 4.32 \\
\hline & Homestay & 6 & 3.24 \\
\hline \multirow{8}{*}{ Source of information } & Internet & 72 & 38.92 \\
\hline & Map & 10 & 5.41 \\
\hline & Friend/Relative words of month & 59 & 31.89 \\
\hline & National government tourist official & 4 & 2.16 \\
\hline & Magazine/Travel Guidebook & 4 & 2.16 \\
\hline & Travel Agency & 26 & 14.05 \\
\hline & TV/Radio & 4 & 2.16 \\
\hline & Expo/ exhibition /Tourist Fair & 6 & 3.24 \\
\hline \multirow{4}{*}{ How much per day } & Less than 1 hour & 48 & 25.95 \\
\hline & 1-4 hours & 110 & 59.46 \\
\hline & 4-8 hours & 23 & 12.43 \\
\hline & More than 8 hours & 4 & 2.16 \\
\hline \multirow{10}{*}{ More enjoyable activities } & Drink in a Bar & 33 & 17.84 \\
\hline & Water Sports & 54 & 29.19 \\
\hline & Eating or Picnic & 2 & 1.08 \\
\hline & Swimming & 4 & 2.16 \\
\hline & Sunbathing & 12 & 6.49 \\
\hline & Walking & 21 & 11.35 \\
\hline & Sight-Seeing & 21 & 11.35 \\
\hline & View and Fresh Air & 32 & 17.30 \\
\hline & Dine at cafe and restaurant & 4 & 2.16 \\
\hline & Children's Play & 2 & 1.08 \\
\hline \multirow{6}{*}{ Dislike } & Litter & 72 & 38.92 \\
\hline & Poor Facilities & 58 & 31.35 \\
\hline & Water Quality & 17 & 9.19 \\
\hline & Sewage & 8 & 4.32 \\
\hline & Noise & 22 & 11.89 \\
\hline & Poor Access & 8 & 4.32 \\
\hline
\end{tabular}

\section{Measurement}

The study adapted all the questions' items in the questionnaire from extant literature and altered them to suit the objectives of this present investigation. It used the 5 -point Likert-scale for the responses (e.g. $1=$ strongly disagree, $2=$ disagree, $3=$ neither agree nor disagree, 4 = agree, $5=$ strongly agree). Six questions items relating to the five 
dimensions of service quality (tangible, reliability, responsiveness, assurance and empathy) were adapted from Parasuraman (1988), whereas the SERVQUAL instrument was utilized to measure expectations and perceptions of customers relating to a particular service transaction. Four questions items relating to tourist revisit intention were adapted from some previous studies (e.g. Lai et al., 2007; Correia \& Pimpão, 2008).

\section{SIGNIFICANT FINDINGS AND RESULTS}

The study used VB-SEM with Smart-PLS to analyze the 185 samples, and to test the study's hypotheses. Firstly, it analyzed the convergent validity which comprises a latent variable, question items, main loadings, average variance extracted (AVE), and composite reliability (CR). It was found that the main loading of all items exceeded the 0.5 value recommended by Hair et al. (2009). However, some of the question items such as E1, E4, R1, R2, R6, T1 and T6 were deleted because their main loadings were lower than 0.50. As for the remaining questions items, their main loadings were greater than 0.60 , with RI2 having the maximum main loading of 0.892.

The study utilized the average variance extracted (AVE) to evaluate the convergent validity, and all constructs have AVE greater than above 0.5. This implies an acceptable level of convergent validity based on Fornel and Larcker (1981). Moreover, tourist revisit intention has an R-square value of 0.558 , and all constructs had composite reliability (CR) greater than 0.80 . This is an indication that it satisfied the rule of thumb recommended by Hair et al. (2013), as well as surpassed the 0.7 value suggested by Hair et al. (2009). The results of the measurement model are shown in Table 4.

Table 4. Measurement model of PLS (IVs on DV) ( $\mathrm{n}=185)$

\begin{tabular}{|c|c|c|c|c|}
\hline \multirow{2}{*}{$\begin{array}{l}\text { Latent variable } \\
\text { Assurance }\end{array}$} & \multicolumn{2}{|c|}{ Question ItemsMain Loading } & AVE & Composite Reliability \\
\hline & $\mathrm{A} 1$ & 0.601 & \multirow{6}{*}{0.529} & \multirow{6}{*}{0.870} \\
\hline & A2 & 0.765 & & \\
\hline & A3 & 0.742 & & \\
\hline & A4 & 0.701 & & \\
\hline & A5 & 0.680 & & \\
\hline & A6 & 0.851 & & \\
\hline \multirow[t]{4}{*}{ Empathy } & E2 & 0.820 & \multirow{4}{*}{0.706} & \multirow{4}{*}{0.906} \\
\hline & E3 & 0.858 & & \\
\hline & E5 & 0.873 & & \\
\hline & E6 & 0.807 & & \\
\hline \multirow[t]{3}{*}{ Reliability } & RE3 & 0.670 & \multirow{3}{*}{0.593} & \multirow{3}{*}{0.813} \\
\hline & RE4 & 0.848 & & \\
\hline & RE5 & 0.783 & & \\
\hline \multirow[t]{6}{*}{ Responsiveness } & RES1 & 0.826 & \multirow{6}{*}{0.651} & \multirow{6}{*}{0.918} \\
\hline & RES2 & 0.775 & & \\
\hline & $\mathrm{RES}_{3}$ & 0.829 & & \\
\hline & RES4 & 0.798 & & \\
\hline & $\mathrm{RES}_{5}$ & 0.794 & & \\
\hline & RES6 & 0.820 & & \\
\hline \multirow[t]{4}{*}{ Tangible } & TAN2 & 0.849 & \multirow{4}{*}{0.559} & \multirow{4}{*}{0.834} \\
\hline & $\mathrm{TAN}_{3}$ & 0.644 & & \\
\hline & TAN4 & 0.718 & & \\
\hline & TAN5 & 0.764 & & \\
\hline \multirow[t]{4}{*}{ Tourist Revisit Intention } & RI1 & 0.838 & \multirow{4}{*}{0.693} & \multirow{4}{*}{0.900} \\
\hline & $\mathrm{RI} 2$ & 0.892 & & \\
\hline & $\mathrm{RI} 3$ & 0.780 & & \\
\hline & $\mathrm{RI}_{4}$ & 0.817 & & \\
\hline
\end{tabular}


This study tested the discriminant validity. In all the cases, the square root of AVEs were above the off-diagonal components in their related row and column, implying that the required discriminant validity was fulfilled. Generally, the measurement model indicated satisfactory convergent and discriminant validity. Fornel and Larcker (1981) posited that the evaluated discriminant validity for each construct's square root of AVE should be greater than the inter-correlations of the construct with the other constructs in the model. Table 5 illustrates the analyses of the confirmed discriminant validity of all constructs.

Table 5. Discriminant validity of measurement model $(\mathrm{n}=185)$

\begin{tabular}{lcccccc}
\hline Variable & Assurance Empathy & Reliability & Responsiveness & Tangible & $\begin{array}{c}\text { Tourist Revisit } \\
\text { Intention }\end{array}$ \\
\hline Assurance & $\mathbf{0 . 7 2 7}$ & $\mathbf{0 . 8 4 0}$ & & & & \\
Empathy & 0.512 & 0.451 & $\mathbf{0 . 7 7 0}$ & & & \\
Reliability & 0.412 & 0.807 & & \\
Responsiveness & 0.643 & 0.809 & 0.607 & $\mathbf{0 . 8 0 7}$ & \\
Tangible & -0.026 & -0.042 & 0.219 & 0.102 & $\mathbf{0 . 7 4 7}$ & \\
Tourist Revisit & 0.467 & 0.395 & 0.397 & 0.588 & 0.482 & $\mathbf{0 . 8 3 3}$ \\
Intention & & &
\end{tabular}

Note: In bold represent the squared root of average variance extracted (AVE) while the other entries represent the correlations

\section{Descriptive statistics of the latent variables}

The statistics indicated that the exact mean value of the six latent variables ranges from 3.294 to 3.586 , while the standard deviation varies from 0.541 to 0.797 based on a 5 -point Likert scale. However, the mean values of all the variables were greater than the midpoint of 2.50. It showed that Tangible had the highest mean value of 3.586, whereas Empathy had the lowest mean value of 3.294. Based on the distribution values reported through the standard deviation it indicated that tourist revisit intention had the highest value of 0.797, whereas Assurance had the lowest value of 0.541. Accordingly, the lowest value of all the six variables varied from 1.50 to 2.33 , whereas the highest value varied from 4.00 to 5.00. The descriptive analysis is shown in Table 6.

Table 6. The results of the descriptive analysis

\begin{tabular}{lccccc}
\hline Latent variable & No of items & Minimum & Maximum & Mean & Std. Deviation \\
\hline Tangible & 4 & 2.25 & 5.00 & 3.586 & 0.656 \\
\hline Reliability & 3 & 2.33 & 5.00 & 3.579 & 0.683 \\
\hline Assurance & 6 & 2.33 & 4.67 & 3.452 & 0.541 \\
\hline Empathy & 4 & 1.75 & 4.00 & 3.294 & 0.611 \\
\hline Responsiveness & 6 & 1.50 & 4.67 & 3.347 & 0.680 \\
\hline Tourist Revisit Intention & 4 & 1.50 & 5.00 & 3.572 & 0.797 \\
\hline
\end{tabular}

\section{Assessment of structural model}

The R-square value of tourist revisit intention is 0.558 , signifying that service quality perception explained $55.8 \%$ of the variance in tourist revisit intention (Figure 3 ). The study measured the path coefficients of the structural model and applied a bootstrap analysis with 500 resamples to test the structural model in order to determine the significance of the direct effects of path coefficients. It evaluated the significant effects stated by the research model. The results showed that the effects of tangible on tourist revisit intention $(\beta=0.447$, t-value $=6.765, p<0.001)$, assurance on tourist revisit intention $(\beta=0.223, \mathrm{t}$-value $=2.129, \mathrm{p}<0.05)$, responsiveness on tourist revisit intention $(\beta=0.499$, $\mathrm{t}$-value $=3.055, \mathrm{p}<0.01)$ were significant and positive. 
Hence, service quality perception had a positive relationship with tourist revisit intention, therefore, $\mathrm{H}_{1}, \mathrm{H}_{3}$ and $\mathrm{H}_{5}$ are supported. Table 7 and Figure 4 indicate the relationship and results. Conversely, the results showed that there is no significant relationship between reliability and tourist revisit intention, as well as between empathy and tourist revisit intention. Thus, $\mathrm{H}_{2}$ and $\mathrm{H}_{4}$ are rejected.

Table 7. Significance of direct effects- Path coefficients $(n=185)$

\begin{tabular}{|c|c|c|c|c|c|c|}
\hline Hypotheses & Path & $\begin{array}{l}\text { Beta- } \\
\text { value }\end{array}$ & $\begin{array}{c}\text { Sample } \\
\text { Mean }\end{array}$ & $\begin{array}{c}\text { Standard } \\
\text { Error }\end{array}$ & t-value & Decision \\
\hline $\mathbf{H}_{1}$ & $\begin{array}{l}\text { Tangible->Tourist } \\
\text { Revisit Intention }\end{array}$ & 0.447 & 0.456 & 0.066 & $6.765^{* * *}$ & supported \\
\hline $\mathrm{H}_{2}$ & $\begin{array}{c}\text { Reliability -> Tourist Revisit } \\
\text { Intention }\end{array}$ & -0.062 & -0.039 & 0.092 & 0.668 & $\begin{array}{c}\text { Not } \\
\text { supported }\end{array}$ \\
\hline $\mathbf{H}_{3}$ & $\begin{array}{c}\text { Assurance -> Tourist } \\
\text { Revisit Intention }\end{array}$ & 0.223 & 0.245 & 0.105 & 2.129* & supported \\
\hline $\mathrm{H}_{4}$ & $\begin{array}{c}\text { Empathy -> Tourist Revisit } \\
\text { Intention }\end{array}$ & -0.076 & -0.066 & 0.117 & 0.651 & $\begin{array}{c}\text { not } \\
\text { supported }\end{array}$ \\
\hline $\mathbf{H}_{5}$ & $\begin{array}{c}\text { Responsiveness ->Tourist } \\
\text { Revisit Intention }\end{array}$ & 0.499 & 0.457 & 0.163 & $3.055^{* *}$ & supported \\
\hline
\end{tabular}

Note: ${ }^{*} \mathrm{p}<0.05,{ }^{* *} \mathrm{p}<0.01,{ }^{* * *} \mathrm{p}<0.001$

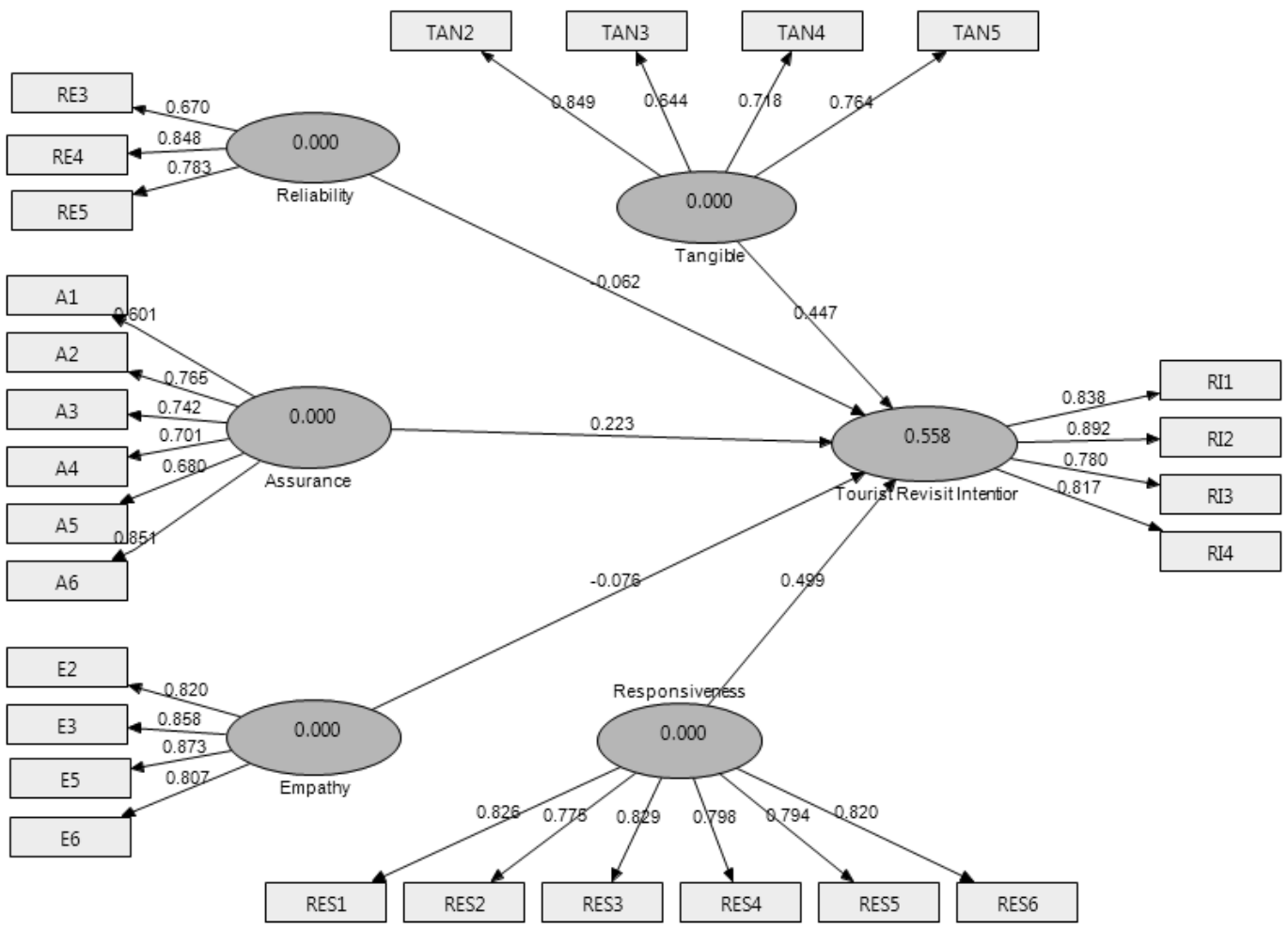

Figure 3. PLS-Path analysis of Beta-value and R-square values $(n=185)$

\section{DISCUSSION}

Public variety shows which differences between social groups could create diverse outdoor entertainment and leisure styles. According to Wolch and Zhang (2004), beach 
usage rates differ considerably by age, class, immigrant status, ethnicity, leisure activity choice as well as the distance between home and beach. The study highlighted the particular indicators that relate the profiles and perceptions of beach users. Tunstall and Penning-Rowsell (1998) opined that local residents may possess special information regarding the local seaside conditions, currents, tides as well as the sources of pollution. The negative perception of residents regarding environmental aspects could be attributed to their daily life in an area, which makes them to have greater knowledge of the influences during the summertime. Essentially, local people have less tolerance to litter, possibly because of their knowledge of its origins (e.g. invasion by visitors and tourism). The views and specifications of leisure places by beach users should be considered in evaluating and guiding beach management practices. The variability of the awareness and needs of beach users were revealed to be partly related to social demographic factors and should be taken into consideration. More precisely, the results of this research could help in identifying the weaknesses in a management model and create new improvements for beach planning (sustaining or eliminating particular beach uses). Moreover, it could also assist to encourage environment, behaviour and the details perceptions of beach users. These could develop recognition, promotion, enhance information policies as well as improve specific unknown constituents including the natural or cultural values of a beach.

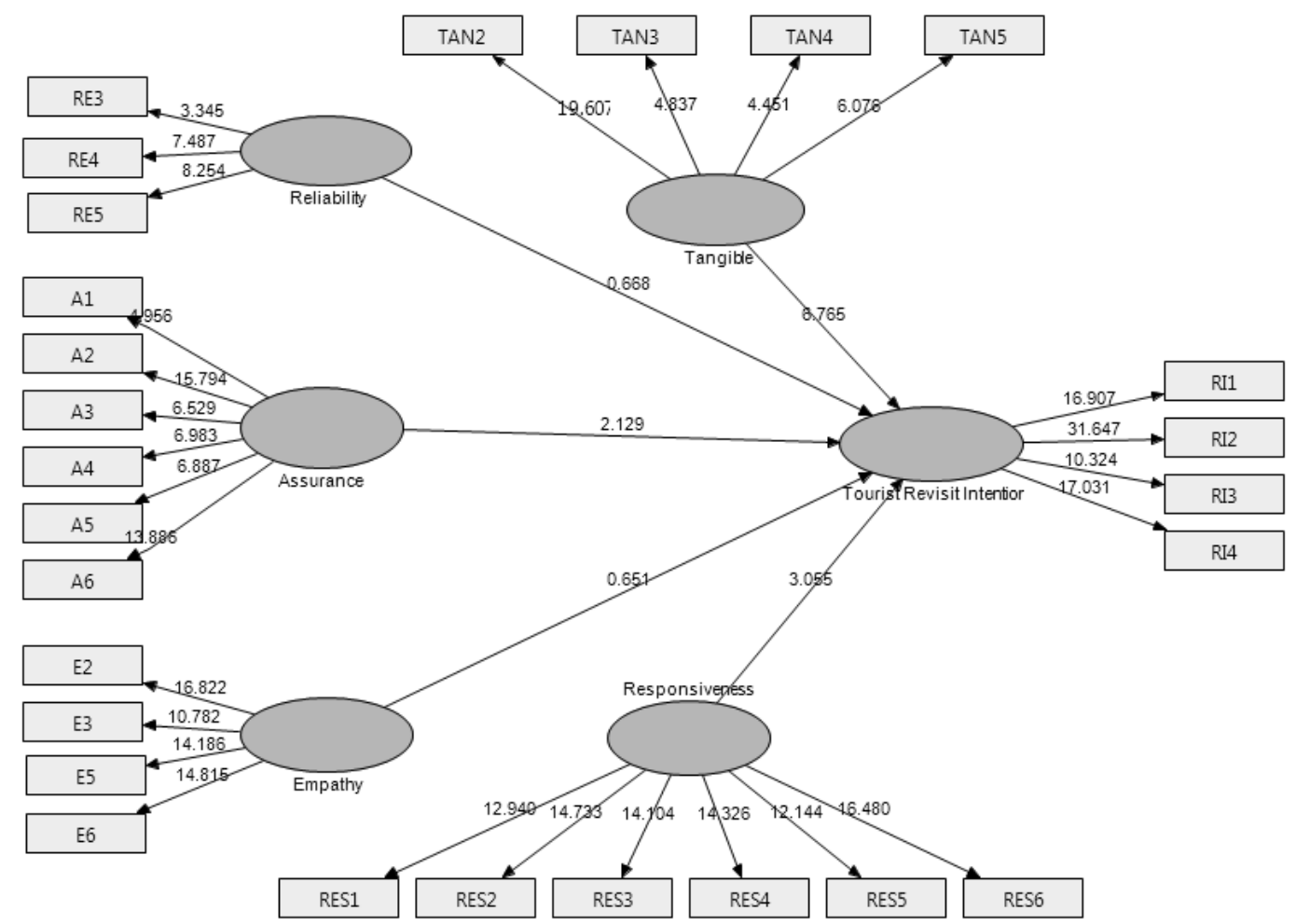

Figure 4. PLS-Path analysis of $\mathrm{t}$-values $(\mathrm{n}=185)$

\section{LIMITATIONS AND FUTURE RESEARCH OPPORTUNITIES}

This study is not, nevertheless, free from limitations. One of the limitations is that we only examined service quality perceptions of international tourists' intentions to revisit 
beach routes. Further studies should be conducted to investigate service quality perceptions of local residents in this area. Furthermore, this study has been conducted on one destination in Malaysia and this can be considered as another limitation of this study.

More studies in other destinations are needed to get more consistent results and generalize the results of the current study. Besides, the current study was conducted with heterogeneous respondents who were from different countries and cultures. These differences among the respondents make an extreme influence on respondents' responses, group and compare the results obtained. Other work should be assumed to amend the existing model with the inclusion of cultural differences not only among international tourists but between residents and international tourists. Attitudinal differences could take the shape of perceptions of traditions, values, beliefs, as well as religious practices.

\section{CONCLUSIONS}

In most of the Mediterranean basin, beaches represent the icons of mass tourism. Hence, the approaches of beach management require substantial effort and accuracy. The scope of beach management practices had expanded in recent years, with several parameters (e.g. public education, safety, water quality, geomorphology and facilities) incorporated into the processes of the evaluation of these practices.

Nonetheless, the models utilized could become homogeneous if the specific features of each beach are negleted, both in terms of natural diversity and social uses. Thus, this current study investigated the perception of service quality by international tourists at Langkawi Island in Malaysia. Evidence from the study showed that assurance, responsiveness and tangible have significant and positive effects on services quality perception, whereas the effects of empathy and reliability were insignificant.

Thus, assurance denotes being safe, and the international tourists indicated that assurance is a vital dimension of the service quality perception. Responsiveness signifies the appropriate response to the needs of the international tourists. This study implied that responsiveness had a positive effect on tourist revisit intention. Some services including infrastructure facilities are necessary since this study suggested that tangibility is significant for delivering quality of service. Reliability is concerned with the accuracy and timeliness of delivering services, but it had insignificant relationship with tourist revisit intention. This study suggested essential perspectives of how to assist service provider to acquire a better understanding of the perception of service quality by international tourists with a view to seeking for ways of improvement.

\section{Acknowledgements}

The authors are grateful to the editor and blind reviewers of the GeoJournal of Tourism and Geosites for their valuable comments and feedback.

\section{REFERENCES}

Aijzen, I. (2002). Perceived behavioural control, self-efficacy, locus of control and the theory of planned behaviour. Journal of Applied Social Psychology, 32(4), 665-683.

Akama, J. S. \& Kieti, D.M. (2003). Measuring tourist satisfaction with Kenya's wildlife safari: a case study of Tsavo West National Park. Tourism Management, 24(1), 73-81.

Andriotis, K. (2004). Problems of island tourism development: The Greek insular regions. Coastal mass tourism: Diversification and sustainable development in Southern Europe, 114-132.

Ananth, A., Ramesh, R. \& Prabaharan, B. (2011). Service Quality GAP Analysis in Private Sector Banks A Customer Perspective. Internationally Indexed Journal, Vol. II, Issue.1 pp., 245-252.

Assaker, G., Vinzi, V. E., \& O'Connor, P. (2011). Examining the effect of novelty seeking, satisfaction, and destination image on tourists' return pattern: A two factor, non-linear latent growth model. Tourism management, 32(4), 890-901. 
Azizzadeh, F., Khalili, K. \& Soltani, I. (2013). Service Quality Measurement in the Public Sector (Ilam Province Post Office Case Studies). International Journal, 2(1).

Bonaiuto, M., Breakwell, G.M. \& Cano, I. (1996). Identity processes and environmental threat: the effects of nationalism and local identity upon perception of beach pollution. Journal of Community \& Applied Social Psychology, 6, 157-175.

Breton, F., Clapés, J., Marquès, A., \& Priestley, G. K. (1996). The recreational use of beaches and consequences for the development of new trends in management: the case of the beaches of the Metropolitan Region of Barcelona (Catalonia, Spain). Ocean \& Coastal Management, 32(3), 153-180.

Carlsen, J. \& Butler, R. (2011). Introducing sustainable perspectives of island tourism. Wallingford: CABI.

Chapman, L. (2007). Transport and climate change. Journal of Transport Geography, 15, 354- 367.

Chen, C. F. \& Tsai, D. (2007). How destination image and evaluative factors affect behavioural intentions. Tourism Management, vol. 28, pp. 1115 - 1122.

Cihar, M. \& Stankova, J. (2006). Attitudes of stakeholders towards the Podyji/Thaya River Basin National Park in the Czech Republic. Journal of Environmental Management, 81, 273-285.

Connell, J. (2006). Medical tourism: Sea, sun, sand and surgery. Tourism Management, 27(6), 1093-1100.

Correia, A. \& Pimpão, A. (2008). Decision-making processes of Portuguese tourist travelling to South America and Africa. International Journal of Culture, Tourism and Hospitality Research, 2(4), 330-373.

Cutter, S.L., Nordstrom, K.F. \& Kuema, G.A. (1979). Social and environmental factors are influencing beach site selection. In Proceedings of the fifth annual conference on resource allocation in issues in the coastal environment (pp. 183-194). The Coastal Society.

Daily, G. C. (Ed.). (1997). Nature's services: Societal dependence on natural ecosystems. Washington: Island Press.

Fredline, E. \& Faulkner, B. (2000). Host community reactions. A cluster analysis. Annals of Tourism Research, $27,763-784$.

Fullana, P. \& Ayuso, S. (2001). Turisme sostenible. Barcelona: Rubes, Departament de Medi Ambient.

Galloway, G. (2002). Psychographic segmentation of park visitor markets: evidence for the utility of sensation seeking. Tourism Management, 23, 581-596.

Gronroos C (1984). A service quality model it's marketing implication. European J. Marketing. 13(4). 36-44.

Holden, A. (2000). Environment and tourism. London: Routledge. Hui, T. K., Wan, D. T. W., Ho, A., Tourists' satisfaction, recommendation and revisiting Singapore, Tourism Management, vol. 28, pp. 965 - 975, 2007.

Kaltenborn, B.P., Thomassen, J. \& Linnell, J.D. (2012). Island futures: Does a participatory scenario process capture the common view of local residents? Futures, 44, 328- 337.

Krzanowski, W.J. (1990). Principles of multivariate analysis. Clarendon Press.

Lai, W.K., Hsiao, S.-Y. \& Lin, Y.-C. (2007). Adaptive backup routing for ad-hoc networks. Computer Communications, 30(2), 453-464.

Lam, T. \& Hsu, C.H.C. (2006). Predicting behavioral intention of choosing a travel destination. Tourism Management, Vol. 27 No. 4, pp. 589-599.

Lehto, X.Y., O’Leary, J.T. \& Morrison, A.M. (2004). The effect of prior experience on vacation behavior, Annals of Tourism Research, Vol. 31 No. 4, pp. 801-818.

Li, M., Cai, L.A., Lehto, X.Y. \& Huang, J. (2010). A missing link in understanding revisit intention-The role of motivation and image. Journal of Travel \& Tourism Marketing, 27(4), 335-348.

Moon, H. \& Han, H. (2019). Tourist experience quality and loyalty to an island destination: The moderating impact of destination image. Journal of Travel \& Tourism Marketing, 36(1), 43-59.

Morgan, R. (1999). Preferences and priorities of recreational beach users in Wales, UK. Journal of Coastal Research, 15 (3), 653-667.

Morgan, R., Jones, T.C. \& Williams, A.T. (1993). Opinions and perceptions of England and Wales Heritage Coast beach users: some management implications from the Glamorgan Heritage Coast, Wales. Journal of Coastal Research, 9, 1083-1093.

Mujan, I., Anđelković, A.S., Munćan, V., Kljajić, M. \& Ružić, D. (2019). Influence of indoor environmental quality on human health and productivity-A review. Journal of cleaner production, 217, 646-657.

Parasuraman, A., Zeithaml, V. \& Berry, L. (2002). SERVQUAL: a multiple-item scale for measuring consumer perceptions of service quality. Retailing: critical concepts, 64(1), 140.

Parasuraman A, Zeithaml V.A. \& Berry L.L. (1998). SERVQUAL: a multiple-item, scale for measuring consumer perception of service quality. J. Retailing. 64(1): 12-40.

Parasuraman, A., Zeithaml, V. \& Berry, L. (1985). A conceptual model of service quality and its implications for future research. Journal of Marketing, Vol. 49 No.4, pp. 41-50.

Park, D.B. \& Yoon, Y.S. (2009). Segmentation by motivation in rural tourism: A Korean case study. Tourism Management, 30(1), 99-108.

Pereira, A.Q. \& Dantas, W.C. (2019). From sea bathing to sports on beaches and sea areas. Sociedade \& Natureza, 31(1), 1-21.

Prata, J.C., Reis, V., Paço, A., Martins, P., Cruz, A., da Costa, J.P. \& Rocha-Santos, T. (2020). Effects of spatial and seasonal factors on the characteristics and carbonyl index of (micro) plastics in a sandy beach in Aveiro, Portugal. Science of The Total Environment, 709, 135892. 
Priestley, G. \& Mundet, L. (1998). The post-stagnation phase of the resort cycle. Annals of Tourism Research, 25(1), 85-111.

Pemayun, A. G.P. \& Suderana, I.W. (2019). Shifting social and economic structural community: rapid development of tourism sector. International journal of social sciences and humanities, 3(1), 115-124.

Priskin, J. (2003). Tourist perceptions of degradation caused by coastal nature-based recreation. Environmental Management, 32, 189-204.

Reimer, A. \& Kuehn, R. (2005). The impact of service scape on quality perception. European Journal of Marketing, 39(7/8), 785-808.

Retama, I., Sujitha, S.B., Rivera, D.R., Shruti, V.C., Rodríguez-Espinosa, P.F. \& Jonathan, M.P. (2019). Evaluation and Management Strategies of Tourist Beaches in the Pacific Coast: A Case Study from Acapulco and Huatulco, Mexico. In Coastal Management (pp. 79-93). Academic Press.

Royle, S.A. (2010). The economics of small island tourism: International demand and country risk analysis. Tourism Management, 31, $291-292$.

Rodella, I. \& Corbau, C. (2020). Linking scenery and users' perception analysis of Italian beaches (case studies in Veneto, Emilia-Romagna and Basilicata regions). Ocean \& Coastal Management, 183, 104992.

Kandampully, J., \& Suhartanto, D. (2000). Customer loyalty in the hotel industry: the role of customer satisfaction and image. International journal of contemporary hospitality management. 12(6), 346-351.

Sadeh, E., Asgari, F., Mousavi, L. \& Sadeh, S. (2012). Factors affecting tourist satisfaction and its consequences. Journal of Basic and Applied Scientific Research, vol. 2, no. 2, pp. 1557 - 2012.

Saner, R., Yiu, L. \& Filadoro, M. (2019). Tourism development in least developed countries: Challenges and opportunities. In Sustainable Tourism: Breakthroughs in Research and Practice (pp. 94-120). IGI Global.

Som, A.P.M. \& Badarneh, M.B. (2011). Tourist satisfaction and repeat visitation; toward a new comprehensive model. International Journal of Human and Social Sciences, 6(1), 38-45.

Song, R., Vanthienen, J., Cui, W., Wang, Y. \& Huang, L. (2019). Towards a comprehensive understanding of the context concepts in context-aware business processes. In Proceedings of the 11th International Conference on Subject-Oriented Business Process Management (pp. 1-10).

Sparks, P., Ajzen, I. \& Hall-box, T. (2002). Perceived behavioral control, self-efficacy, locus of control, and the theory of planned behavior. Journal of Applied Social Psychology, 32, 665-683.

Tretiakova, T.N., Brankov, J., Petrović, M.D., Syromiatnikova, Y.A., Radovanović, M.M. \& Mikhailovich Yakovlev, A. (2019). Tourism and Natural Environment in The NP TAGANAY (RUSSIA)-Habits and Perceptions of The Visitors. Geojournal of Tourism and Geosites, 25 (2), 595-608.

Tudor, D.T. \& Williams, A.T. (2003). Public perception and opinion of visible beach aesthetic pollution: the utilisation of photography. Journal of Coastal Research, 1104-1115.

Tunstall, S. M. \& Penning-Rowsell, E. C. (1998). The English beach: experiences and values. The Geographical Journal, 164(3), 319-332.

Van Vuuren, T., Roberts-Lombard, M. \& Van Tonder, E. (2013). Customer satisfaction, trust and commitment as predictors of customer loyalty within an optometric practice environment. Southern African Business Review, 16(3), 81-96.

Villares, M. (1999). Percepcio' dels impactes este `tics i mediambientals de la regeneracio’ de platges. Ediciones UPC. (Forum Virtual collection, Barcelona, 2000).

Villares, M., Roca, E., Serra, J. \& Montori, C. (2006). Social perception as a tool for beach planning: a case study on the Catalan coast. Journal of Coastal Research, 48, 118-123, (SI).

Wang, D. (2004). Tourist behavior and repeat visitation to Hong Kong, Tourism Geographies, Vol. 6 No. 1, pp. 99-118.

Williams, A.M. \& Hall, C.M. (2000). Tourism and migration: new relationships between production and consumption. Tourism Geographies, 2(1), 5-27.

Williams, A.T., Gardner, W., Jones, T.C., Morgan, R. \& Ozhan, E. (1993). A psychological approach to attitudes and perceptions of beach users: implications for coastal zone management. In The first international conference on the Mediterranean coastal environment, MEDCOAST'93, Antalya, Turkey (pp. 217-228).

Williams, J. \& Lawson, R. (2001). Community issues and resident opinions of tourism. Annals of Tourism Research, 28(2), 269-290.

Wolch, J. \& Zhang, J. (2004). Beach recreation, cultural diversity and attitudes toward nature. Journal of Leisure Research, 36(3), 414-443.

Submitted:

26.12.2019
Revised:

01.04.2020
Accepted and published online 09.04.2020 